formation was probably an abnormal arteriovenous communication and the spinal cord necrosis due to bypassing of the normal capillary bed with venous thrombosis as an added factor.

I have now come to the end of this survey of my experience of vascular disorders of the spinal cord. Charcot in I870 wrote 'vascular disorders whether due to embolism or thrombosis are unknown in the spinal cord'. Perhaps I have convinced you by these cases that in the occasional case a myelopathy has a vascular basis.

Finally I wish to thank the many clinicians and pathologists principally of the Oxford region but also sometimes further afield who were responsible for that vital portion of anatomy, the spinal cord, coming to me for examination.

\title{
REFERENCES
}

Hughes, J. T. (1964a). Brit. med. F. In press.

Hughes, J. T. (1964b). Int. F. Paraplegia, 2, I.

Hughes, J. T. \& BRownel L, B. (1964). Neurology (Minneap.). In press.

Hughes, J. T. \& McIntyre, A. G. (I963). F. Neurol. Neurosurg. Psychiat, 26, 4I8.

\section{THE DISTURBANCE OF CIRCULATION IN TRAUMATIC PARAPLEGIA IN ACUTE AND LATE STAGES: A PATHOLOGICAL STUDY}

\author{
By Lionel Wolman, M.A., M.D., Ph.D., M.R.C.P., D.P.M. \\ Department of Neuropathology, Royal Infirmary, Sheffield 6
}

THE material on which this investigation of the circulatory disturbances occurring in traumatic paraplegia is based consists of the autopsy findings in 95 cases examined in the period 1952 to I963. Most of these cases had been admitted to the Spinal Injuries Centre at Lodge Moor Hospital, Sheffield, under the care of Dr. A. G. Hardy. Being a post-mortem pathological study, no physiological observations on the circulation during life are included. As full autopsies were carried out in these cases it has been possible to divide the pathological findings into those vascular disturbances encountered in the general examination and those found on detailed investigation of the damaged spinal cord.

TABLE I

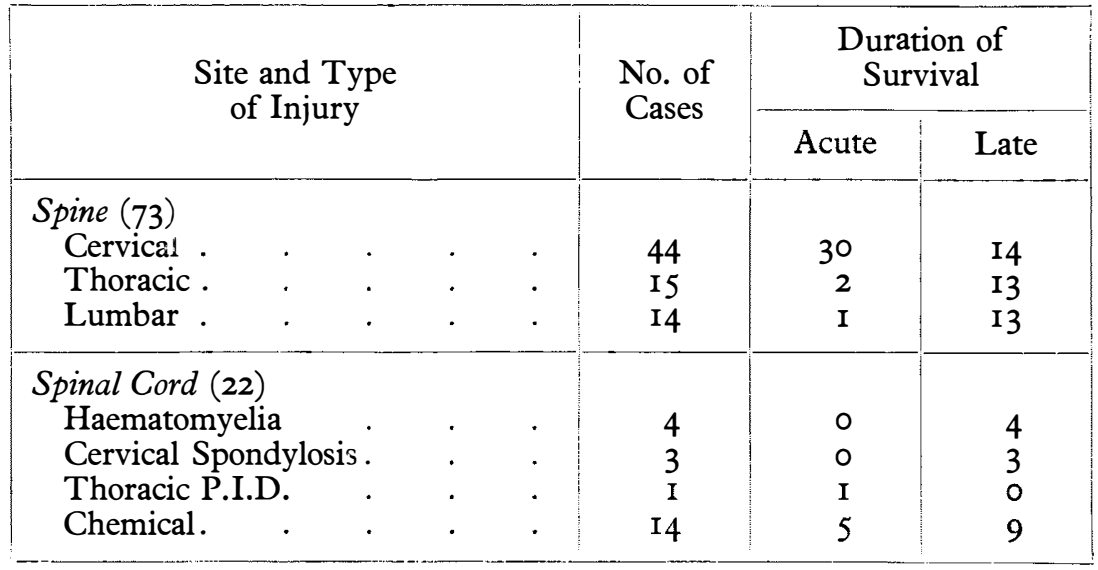


For the purposes of this study, patients dying within one month of their injury were considered to be in the acute stage of traumatic paraplegia whereas those surviving for a longer period were regarded as being in the late stage. The cases were divided into a group in which paraplegia resulted from bony injury to the vertebral column (73 cases) and the remainder in which the spinal cord was damaged without fracture or dislocation of the spine (22 cases), as shown in Table I.

\section{DISTURBANCE OF GENERAL CIRCULATION IN PARAPLEGIA}

Acute Stage. The two main pathological disturbances to the general circulation encountered in the acute stage of paraplegia were: (I) Pulmonary Embolus; (2) Pulmonary Oedema.

I. Pulmonary Embolism. In five cases pulmonary embolism was the cause of fatility. Table II shows the details of the type and site of injury in these cases and the duration of survival. Although 25 out of the 73 cases with bony injuries of the spine survived over two years and as long as 30 years, the occurrence of pulmonary embolism in either subacute or chronic paraplegia was not encountered. This confirms the observations of Tribe (1963), who found no cases of pulmonary embolism in 122 post-mortems on chronic paraplegics.

TABLE II

Analysis of Five Cases of Fatal Pulmonary Embolism

\begin{tabular}{|c|c|c|c|c|c|c|}
\hline \multicolumn{2}{|c|}{ Sex and Age } & $\begin{array}{l}\text { Type of } \\
\text { Injury }\end{array}$ & $\begin{array}{c}\text { Bony } \\
\text { Damage }\end{array}$ & $\begin{array}{l}\text { Level of } \\
\text { Injury }\end{array}$ & $\begin{array}{c}\text { Surgical } \\
\text { Treatment }\end{array}$ & $\begin{array}{l}\text { Survival Time } \\
\text { Since Injury }\end{array}$ \\
\hline $\begin{array}{l}\mathrm{F} \\
\mathrm{M}\end{array}$ & $\begin{array}{l}59 \\
34\end{array}$ & $\begin{array}{l}\text { Fell in bath } \\
\text { Dived into sea }\end{array}$ & $\begin{array}{l}\text { Acute P.I.D. } \\
\text { Fracture }\end{array}$ & $\begin{array}{l}\text { C6-7 } \\
\text { C4-5 }\end{array}$ & $\begin{array}{c}-\overline{\text { Skull }} \\
\text { Traction }\end{array}$ & $\begin{array}{c}6 \text { days } \\
4 \text { weeks }\end{array}$ \\
\hline M & 54 & Fall of coal roof & $\begin{array}{l}\text { Fracture } \\
\text { Dislocation }\end{array}$ & DII-I2 & $\begin{array}{l}\text { Plated } \\
\text { Same } \\
\text { Evening }\end{array}$ & IO days \\
\hline$M$ & 46 & Fall of coal roof & $\begin{array}{l}\text { Fracture } \\
\text { Dislocation }\end{array}$ & D9-IO & - & 4 weeks \\
\hline$M$ & 37 & Pit accident & $\begin{array}{l}\text { Fracture } \\
\text { Dislocation } \\
\text { Fractured Ribs } \\
\text { and Sternum }\end{array}$ & $\mathrm{D}_{4-5}$ & - & 4 weeks \\
\hline
\end{tabular}

The incidence of pulmonary embolism was found by Tribe (1963) to be 6 out of 28 cases $(2 \mathrm{I} \cdot 4$ per cent.) dying in the early stages of paraplegia. In the present series there were 5 fatalities from this cause in a series of 33 acute cases $(15.2$ per cent.). Thus although about one-fifth of the cases dying in the early stages of paraplegia will have pulmonary embolism, this complication is very much rarer in any large series which includes long survival cases. This is borne out by the scanty references to pulmonary embolism in paraplegics found in the literature by Tribe. In the five articles quoted (Munro, I943; Lord \& Bunts, 1956; Dietrick \& Russi, 1958; Breithaupt et al., 196I; Durbin, I96I) only 7 cases of pulmonary embolus were encountered in a total of 218 paraplegics who had died.

The site of origin of the embolus was in the leg veins in four out of the five cases. In one case, the miner aged 46 with a fracture dislocation of D9-Io, throm- 
bosed veins were found in the pelvis, especially round the bladder which was acutely infected. There were associated bony injuries to the ribs and sternum in only one case. Two out of the five cases had undergone some form of surgical treatment.

Thus despite the enforced immobility as a result of the paraplegia the incidence of pulmonary embolism is not great compared with the potential risk involved. It occurs during the first monthafter injury and provided this period has passed without this unfortunate complication there is little or no risk of it occurring subsequently.

2. Pulmonary Oedema. Intense oedema of the lungs was a very frequent finding at autopsy in acute cervical spine injuries. Out of 44 cases of injury to the cervical spine 30 (68 per cent.) died within I I days of the accident with an average duration of survival of five days. Of these 30 cases 23 were considered to have died of acute respiratory failure accompanied by severe pulmonary oedema in 20 and massive pulmonary collapse in 3 .

Pulmonary oedema has been found in association with injuries to the central nervous system, both in cerebral and in cervical cord trauma. Thus Vincent and Bernard (I926) noted its association with trauma in patients without evidence of heart disease and described it in cases of encephalitis. Antonini and Biancolani (1927) reported a number of cases of traumatic injury of brain and spinal cord in which pulmonary oedema occurred whilst the association with spinal trauma was noted by Cornil et al. (1930). Hess (1934) reported it in trauma as well as in cases of brain tumour, epilepsy, and in diseases of the peripheral vagus. Weisman (1939) found it in two-thirds of 686 cases of intracranial haemorrhage and in only 2 per cent. of controls. The occurrence of pulmonary oedema after a puncture wound of the medulla oblongata was reported by Schlesinger (I945).

Baker (1957) demonstrated bilateral damage to the dorsal nuclei of the vagus and to the medial reticular nuclei in Io patients with bulbar poliomyelitis dying with pulmonary oedema but not in 5 others without oedema. Reversible pulmonary oedema was described in acute disseminated sclerosis by Elliot (I955).

As a result of these observations the concept of a neural mechanism in the production of pulmonary oedema possibly due to a direct neurogenic vasodilatation of the pulmonary vasculature was propounded. However, pulmonary oedema is a common necropsy finding in patients dying from hypertensive heart disease, chronic nephritis, coronary obstruction and mitral stenosis (Cameron, I948). It was claimed by Paine et al. (1952) that pulmonary oedema and congestion are less common in patients dying after significant disease of the central nervous system ( 46 per cent.) than in those who died of other major illnesses (6o per cent.). They found hypertension and/or heart disease in three-quarters of those with central nervous system lesions and concluded that an essentially cardiac origin of the odema was likely. Richards (1963) found the incidence of pulmonary oedema higher in patients dying with intracranial lesions than in controls. As the oedema was often confined to one or both upper lobes a combination of general and local factors was invoked.

Sarnoff and Sarnoff (I952) suggested 'neurogenic' pulmonary oedema resulted indirectly from haemodynamic alterations due to increase in pulmonary capillary pressure mediated through efferent nerve pathways to the cardiovascular system, and introduced the term 'neurohaemodynamic pulmonary oedema'.

The results obtained in the production of pulmonary oedema in the experimental animal are equally confusing. Campbell et al. (1949) using a subdural balloon inserted over the cerebrum of a dog, demonstrated that increased intra- 
cranial pressure can produce acute pulmonary oedema. This was preceded by a rise in both pulmonary arterial and venous pressure but was not accompanied by arterial hypertension. There was bradycardia and lowered cardiac output suggesting a vagal pathway. Similar results were found in dogs by Harrison and Liebow (1952) and in the guinea-pig by Campbell and Visscher (I949).

Another way in which acute pulmonary oedema has been produced in rats and rabbits by Cameron and De (1949) and in dogs by Sarnoff and Berglund (1952) was by the intracisternal injection of thrombin and fibrinogen. This appears to be a non-specific irritative action as veratrine intracisternally in rabbits, has the same effect (Jarisch et al., 1939; Horst et al., 1950). Acute pulmonary oedema was caused in rats by intraperitoneal injection of large doses of ammonium salts (Cameron \& Sheikh, I95I). Some evidence that this was of sympathetic nervous origin was deduced from the fact that premedication of the animals with sympatholytic drugs inhibits the oedema and section of the spinal cord at or above TI had a similar effect.

Discrete bilateral lesions of the anterior hypothalamus or paraventricular nuclei has resulted in pulmonary oedema in rats (Gamble \& Patton, 1953; Maire \& Patton, 1956). It has been known for a long time that bilateral vagotomy in guineapigs (Farber, I937), rats and dogs (Brunn, I932) will produce pulmonary oedema. This was confirmed in guinea-pigs by Borison and Kovacs (1959), who produced it also by bilateral lesions of the vagal nuclei and by transecting the spinal cord at $\mathrm{C}_{7}$ but not at T8. The oedema from cervical cord section did not occur when made in decerebrate guinea-pigs. Some attempt to implicate humoral factors was made by Rech et al. (1962), who induced pulmonary oedema in the normal guinea-pig as a result of cross circulation with a vagotomised animal.

Thus in the production of pulmonary oedema, cardiovascular factors, neurogenic and humoral influences on pulmonary capillary permeability have all been incriminated. The conflicting observations may be due to species variability and lack of adequate controls. The causes of pulmonary oedema and the relevant mechanisms were reviewed by Visscher et al. (1956). In elevating the pulmonary capillary pressure which preceded the oedema, such factors as increased intracranial pressure acting through either the vagal stimulation or sympathetic discharge, bilateral vagotomy and respiratory obstruction due to either inspiratory or expiratory resistance played a part.

Injury to the cervical cord by interrupting sympathetic pathways from hypothalamus to thoracic cord and by impairing the action of respiratory muscles would tend to slow down the heart rate, increase the atrial pressure, distend the right side of the heart and lead to pulmonary oedema.

It may well be as suggested by Paine et al. (1952) that the state of the lungs as found at necropsy may be determined by the events immediately prior to death. If respiration ceases before cardiac function diminishes, blood would be driven through hypoxic lung tissue and the gradual failure of the heart would lead to transudation. If on the other hand the heart action failed before the onset of respiratory failure there would be little tendency to transudation owing to lack of transuding force.

Late Stage. The only common pathological disturbance which was found at autopsy in the late stage in five cases was heart failure due to coronary thrombosis. All except one survived over two years after injury. This exception was a man aged 82 who died six weeks after trauma to the dorsal spine. One case occurred 
after a cervical injury, two in thoracic and two in lumbar spinal injuries. One of the patients with thoracic spinal injury was a severe hypertensive. All the cases were in an age-group in which coronary thrombosis commonly occurs. Thus the condition does not seem related in any way to paraplegia and occurred independently.

\section{DISTURBANCE OF SPINAL CORD CIRCULATION IN PARAPLEGIA}

Acute Stage. The pathological disturbances of the circulation in the spinal cord commonly found consist of :

I. Haemorrhage. As a result of trauma, haemorrhage may occur either in the cord substance or in its covering membranes. In the latter condition only subarachnoid haemorrhage was a common finding in the present series and although subdural and extradural haemorrhages were encountered they were rare and never sufficiently severe to cause compression of the cord.

Haemorrhage in the cord was a very frequent finding usually involving the grey matter most extensively but spreading into the adjacent white matter (fig. I). Although sometimes confined to the damaged segments, more frequently it

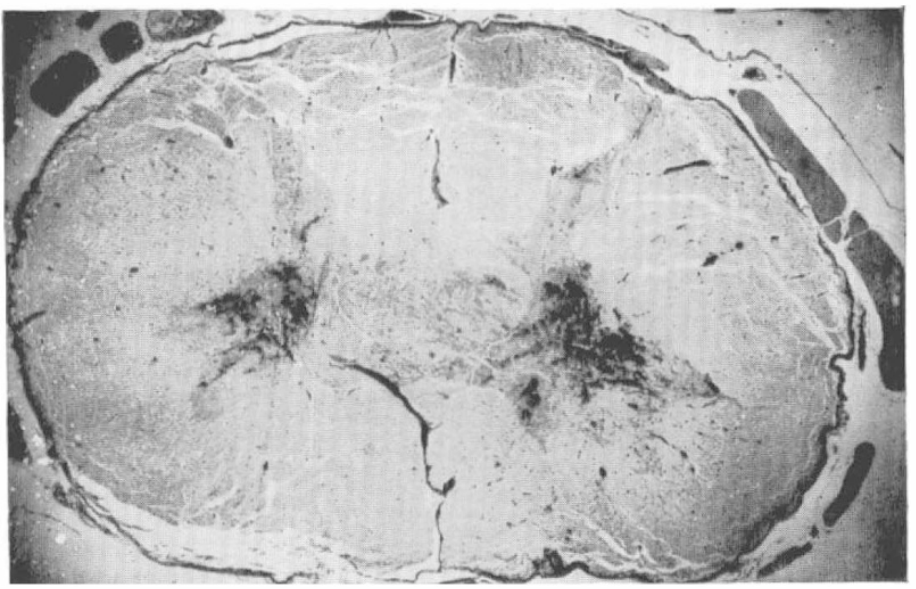

Fig. I

Transverse section of spinal cord at $\mathrm{C}_{7}$ showing haemorrhage in grey matter. Male, aged 26. Fracture $\mathrm{C}_{5}-6$ three days previously.

$($ Silver $\times 7$.

extended upwards and downwards in the form of a tapering elongated tube involving as many as a dozen segments. The whole of the $\mathrm{H}$ shape of the grey matter could be implicated or the haemorrhage could be confined to one side or to one or both posterior horns which were more frequently and more extensively involved than the anterior horns. Many of the haemorrhages were of petechial type due to diapedesis initially appearing in perivascular spaces and spreading into the adjacent tissue but larger haemorrhages due to vessel rupture also occurred. Some of the haemorrhages coalesced into larger areas and the intervening and surrounding tissue became oedematous and necrotic with foci of lymphocytes and polymorphs (fig. 2). Occasionally large blood-filled cavities were found usually in the grey matter and these could persist long after injury (fig. 3). Dilated and congested vessels were prominent in the neighbouring tissue. 
It seems likely that the greater tendency for haemorrhage to occur in the grey matter than in the white must be related to a richer blood supply and to a softer less rigid consistency of the tissue. This latter feature would also tend to allow haemorrhage to spread up and down the cord rather than transversely due to the anatomical boundaries formed by the long compactly arranged fibre tracts.

2. Contusion. Although bleeding into the cord substance was a very frequent accompaniment of contusion, haemorrhage recognisable by the naked eye was not always present. The contused segment appeared darker in colour, being a bluish red when seen immediately after injury. The pia arachnoid was usually intact but appeared distended due to marked swelling of the cord. On sectioning, the line of demarcation between grey and white matter had disappeared giving a soft pulpy appearance to the whole cross-section. The lesion was never a single transverse one involving one or two segments at the site of direct injury. It always extended in a tapering fashion for two or three segments both above and below the most damaged

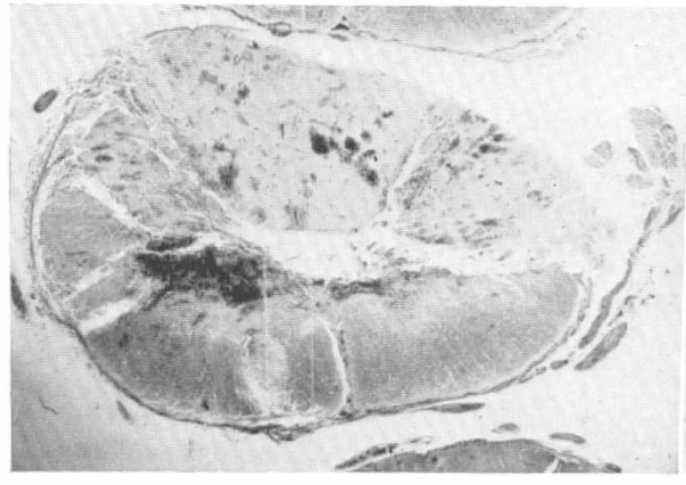

Fig. 2

Transverse section at $\mathrm{C}_{5}$ showing haemorrhagic softening of dorsal half and haemorrhage in anterior horns, Male, aged 59. Fracture of $\mathrm{C}_{3}, 6$ and 7 five days previously. (Mallory's PTAH $\times 5$.)

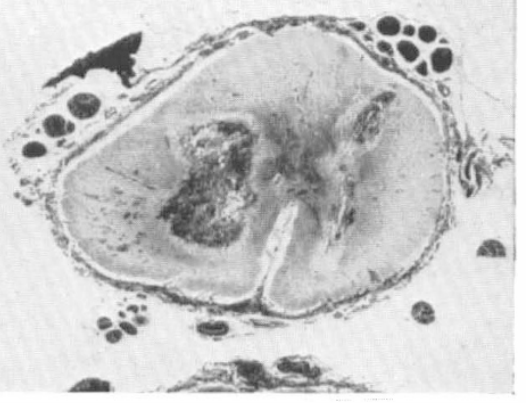

FIG. 3

Transverse section at D9 showing old haemorrhage in the grey matter. Male, aged 37. Fracture of Di2 seven years previously. (Mallory's PTAH $\times 5$.

level. The mechanism of this form of damage appeared to be acute compression of the cord by the fractured or dislocated vertebrae.

Microscopically the white matter was oedematous, vacuolated and pale staining often with a honeycombed appearance. Many axis cylinders became irregularly swollen, tortuous and fragmented. The earliest haemorrhages appeared as small collections of red cells often round congested capillary vessels and extending into the surrounding tissue. They were situated in the grey matter of the cord usually in the ventral part of the posterior horns extending both dorsally and ventrally into the anterior horn and into the adjacent white matter of the posterior and lateral columns (fig. 4).

3. Compression. Compression of the cord is more likely to occur in fracture dislocations than in any other type of injury, but it can also result from prolapse of an intervertebral disc. If the compression is of only short duration then the effects on the cord will be the same as those seen in contusion. If the degree and duration of compression are greater the effects on the cord and especially on its blood supply will be more severe. The cord appeared narrow and constricted with 
marked swelling due to oedema above and below. On sectioning there was loss of demarcation between grey and white matter, with a greyish haemorrhagic appearance and with a soft mushy consistency.

Microscopically the cord destruction involved maximally the posterior half of the cord although it was sometimes confined to only the postero-lateral white matter. Often haemorrhage occurred in the grey matter spreading into the adjacent white matter. Thrombosed vessels were recognised in the pia arachnoid both on the dorsal aspect and in the ventromedian fissure in acute cases, but these will be described in the next section.

4. Thrombosis. Involvement of the vertebral arteries in cervical spine injuries has been described after manipulation of the neck (Pratt-Thomas \& Berger, I947; Ford \& Clark, I956) and after birth injury (Yates, 1959). The central and dorsal

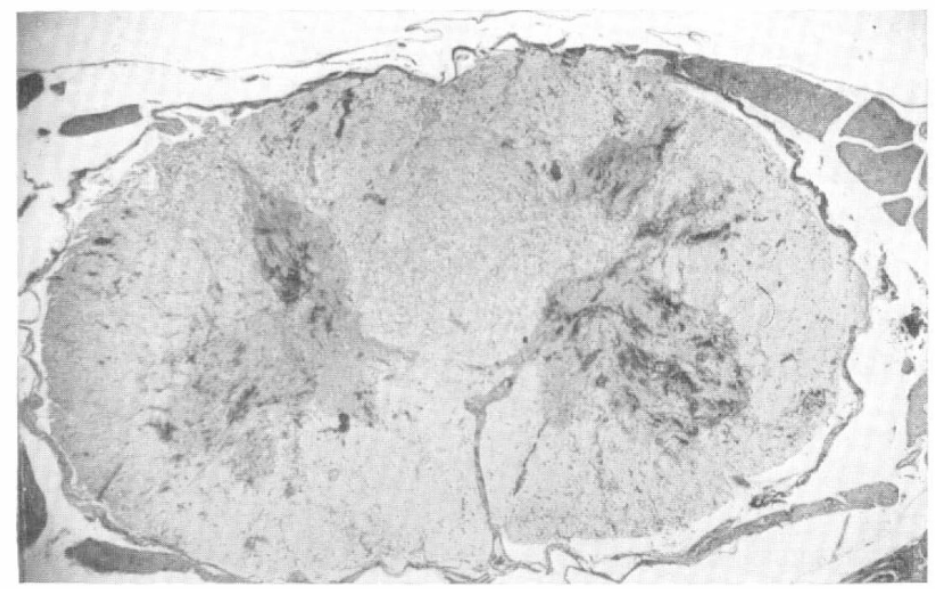

FIG. 4

Transverse section at $\mathrm{C}_{7}$ showing haemorrhages predominantly in the grey matter. Male, aged 60. Eight day survival after fracture dislocation $\mathrm{C}_{5}-6$. (H. \& E. $\times 8$.)

necrosis of the cervical spinal cord after cervical injury was illustrated by Schneider et al., (1958) although no thrombosed vessels were seen. Hughes (I964) recently reported two cases of cervical spine injury without any radiological evidence of fracture or dislocation. At autopsy tearing of the C5-6 disc was found with kinking of the vertebral arteries in their intravertebral course. The cervical cord showed central infarction.

In the present series, necrosis of the cervical cord was encountered to a greater or lesser extent in most cases. In about a third of these cases small pial arteries or intramedullary vessels were seen to be occluded with fibrin thrombus. Almost all these cases had fractures and/or dislocations with direct contusion of the cord. In only two cases was involvement of the vertebral artery found. A 73-year-old man sustained a fracture dislocation of $\mathrm{C}_{5}-6$ with incomplete tetraplegia. Seven days later he became unconscious and died after a further two days. The terminal part of the right vertebral artery and posterior inferior cerebellar artery were occluded with recent thrombus but these vessels were extremely atheromatous at the site of the thrombosis. The other case (Jefferson, personal communication) 
is not included in the autopsy series and concerned a 52-year-old miner who became deeply unconscious with cessation of respiration I8 days after sustaining a subluxation of C5-6. Immediate artificial respiration and posterior fossa decompression with removal of necrotic cerebellar tissue on the right side permitted recovery. Subsequent angiography demonstrated a blocked right vertebral artery.

The delayed onset of cerebral symptoms (7 days, I 8 days) in these two cases could be interpreted as due to thrombosis occurring in diseased vessels due to a sluggish circulation in an immobilised patient. The occlusion occurred at a site of severe atheroma in the first case. The fact that kinking of the vertebral arteries can occur as a result of neck injury may well have contributed to the occlusion, especially in the second case. Thus in our experience vertebral artery involvement has affected the brainstem and cerebellum rather than the cervical spinal cord as in the case recorded by Suechting and French (1955).

Occlusion of one of the major spinal arteries of traumatic origin is a rare occurrence and was described in the anterior spinal artery after injury to the cervical spine by Grinker and Guy (1927). In the present series of cases, it was encountered only on three occasions. In the first case, it resulted from the trauma of the operative removal of a prolapsed thoracic intravertebral disc. The whole crosssection of the cord over the affected segments, DI I and Di2, was involved, being converted into a thin rim of dense glial tissue enclosing large cystic spaces. The second case occurred after a fracture dislocation of DI 2 on LI and caused necrosis of the 3 rd and 4 th sacral segments. The third case resulted from a fracture dislocation of $\mathrm{D}_{5}-6$.

Occlusion of one or more of the smaller pial arteries was seen more frequently. It was encountered in the cervical region in I 4 cases, in 4 cases where the thoracic spine was damaged and in 2 cases where the lumbar spine was injured. The thrombosed vessels were small pial arteries which were either in the ventromedian (8 cases) or dorsomedian ( 2 cases) fissures or on the dorsal aspect of the cord ( 5 cases). In the remaining cases (5) the occluded vessels were in the cord itself, either in the posterior or anterior horns (fig. 5).

The area of cord which showed necrosis was either around the occluded intra-

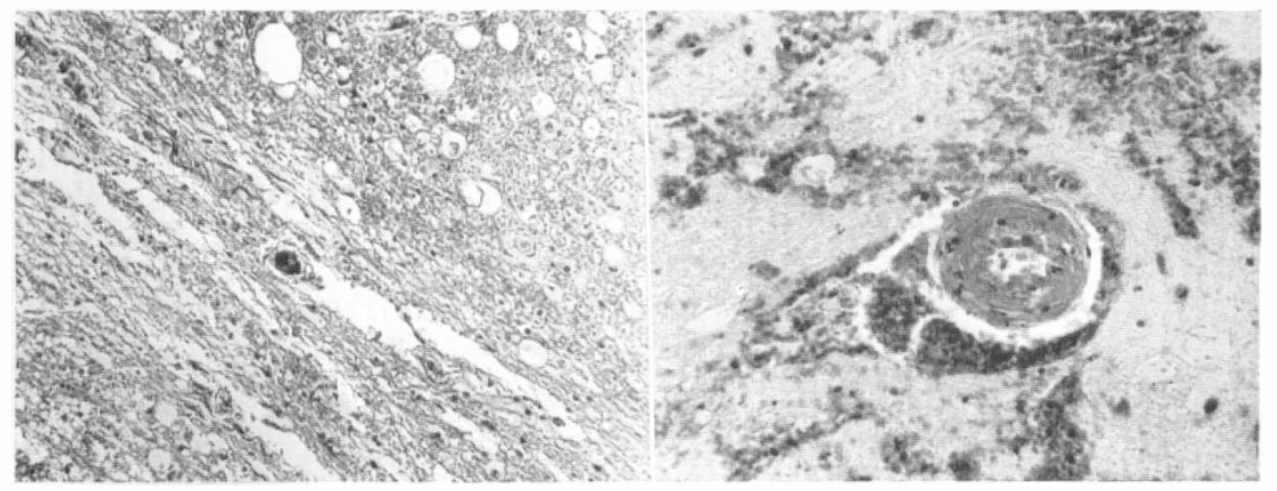

FIG. 5

(a) Small thrombosed artery in posterior horn at C6. Male, aged 63. Four days after flexion injury of neck. (Mallory's PTAH $\times$ I 30.) (b) Small thrombosed artery in haemorrhagic anterior horn at $\mathrm{C}_{7}$. Male, aged 27. Six days after dislocation C6-7. (H. \& E. × I 50.) 
medullary vessel or in the segment adjacent to the thrombosed pial vessels. Occasionally the whole cross-section of the cord became necrotic and in these cases thrombosed vessels were seen on both dorsal and ventral aspects. Arteries occluded by recent fibrin thrombus were found in the nerve roots of the cauda equina (fig. 6) and in the substance of the damaged coccygeal segment of the spinal cord in one case with a fracture dislocation of LI-2 dying from fat embolism 24 hours after multiple injuries.

Pial veins occluded with thrombus were found in two cases of cervical cord trauma and in these the adjacent arteries were also occluded. Venous thrombosis with necrotic myelitis was seen in the lower cervical cord in one case which had phenol injected intrathecally for intractable pain from malignant disease (fig. 7). As the thrombosed veins were seen in the pia arachnoid on the dorsal aspect of the

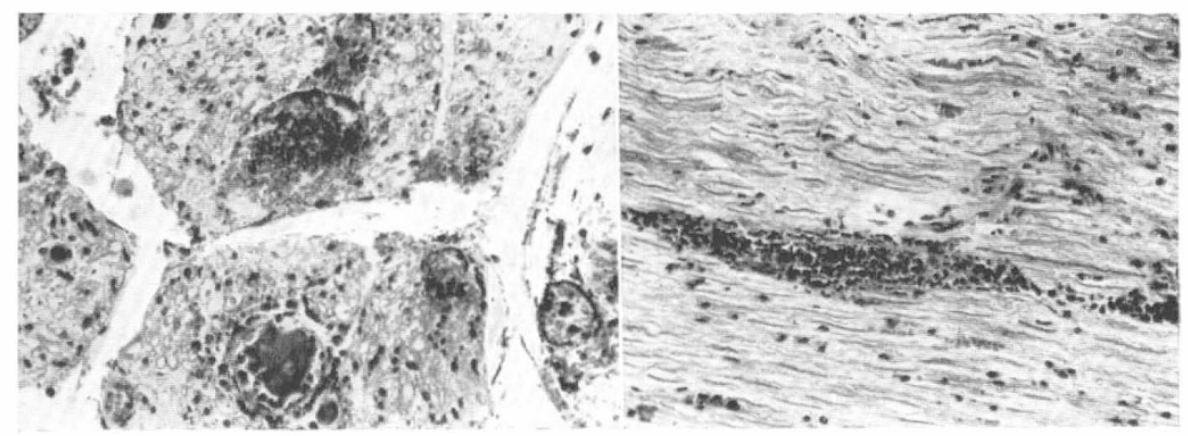

FIG. 6

(a) Thrombosed artery surrounded by polymorphs in nerve root of cauda equina. Haemorrhage has occurred in adjacent nerves. Male, aged 26 . Survived 24 hours after fracture dislocation LI-2. (H. \& E. × I3O.) (b) Longitudinal section of cauda equina from same case showing tortuous fragmented axis cylinders and perivascular foci of polymorphs.

(H. \& E. $\times$ IOO.)

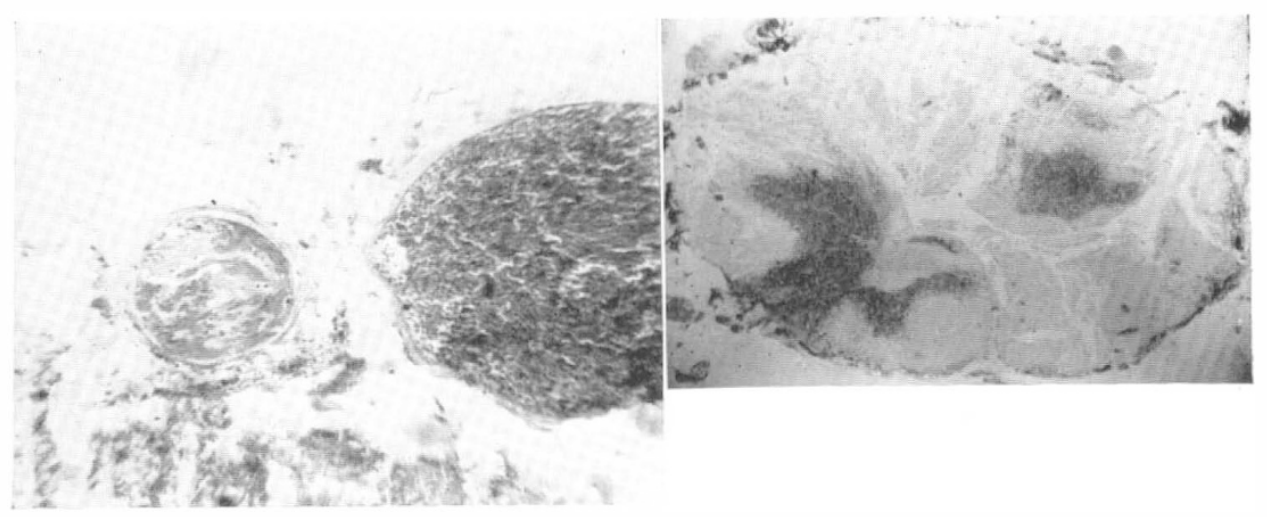

FIG. 7

(a) Fibrin thrombus occluding small vein on dorsal aspect of cord at C6. Male, aged 67. Given phenol intrathecally by injection at $\mathrm{C}_{4}-5$ twelve days previously. (H. \& E. $\times 8$ o.) (b) Transverse section at C8 from same case showing necrotic myelitis. Only a few islands of intact myelin are present. $\quad($ Myelin $\times 9$. $)$ 
C6 and $\mathrm{C}_{7}$ segments and the phenol had been injected at $\mathrm{C}_{4}-5$, the onset of paraplegia within 48 hours was attributed to this, especially as no metastases were found in or near the spinal cord.

The importance of disturbances of venous circulation and drainage in the pathogenesis of remote lesions of the spinal cord after cervical injuries has been emphasised by Jellinger (I964).

Late Stage. The vascular and circulatory pathological changes encountered in the late stages are really sequelae of most of the occurrences of the acute stage.

I. Haemorrhage. After haemorrhage in the cord there was a breaking down of red cells, phagocytosis of haemosiderin pigment by compound granular corpuscles and glial proliferation. The eventual picture was one of patchy areas of gliosis which became extended longitudinally owing to secondary degeneration of fibre tracts or cystic areas of varying size bound by dense glial tissue. Scattered histiocytes filled with haemosiderin were present in this glial wall giving it a golden brown colour.

2. Haematomyelia. Three types of intramedullary haemorrhagic cavities extending over several segments were encountered in this investigation. The most common type was usually small in size and confined to the segments directly involved in the trauma. The earliest stage in their formation was seen four to six weeks after injury when there was cystic breakdown of the haemorrhagic tissue in which were numerous compactly grouped histiocytes. Between the 2nd and 3rd months after injury these histiocytes became less numerous and the cavities more cystic, being surrounded by a layer of gliosed cord tissue and grossly thickened pia arachnoid. The cavities were often multiple, being separated by strands of glial fibres. They were almost always associated with a fracture dislocation of vertebrae and can therefore be regarded as a late effect of compression (fig. 8).

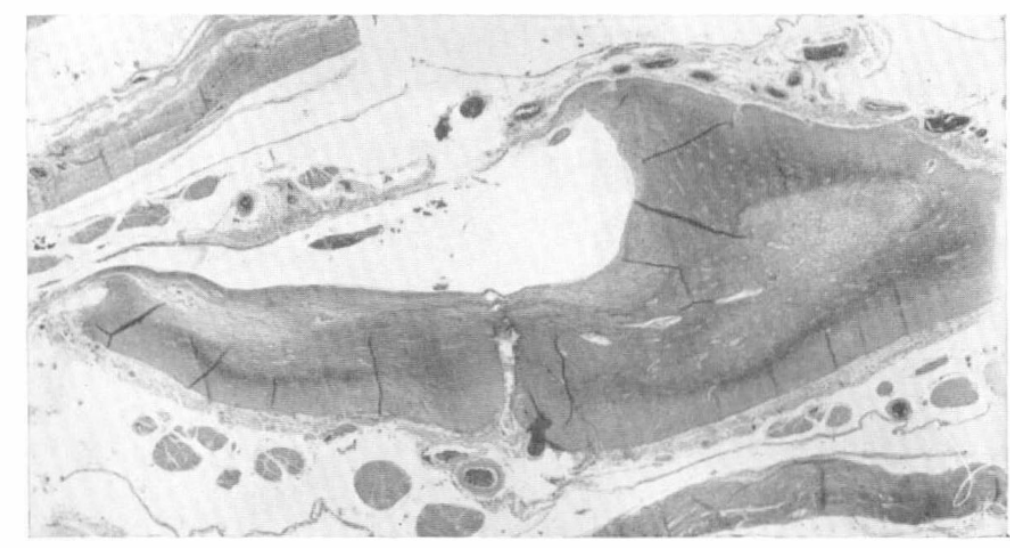

FIG. 8

Transverse section at $\mathrm{L}_{3}$ showing cystic cavity confined to dorso-lateral quadrant. Male, aged 37. Survived I $8 \frac{1}{4}$ years after fracture dislocation Di2-Li. (Mallory's PTAH $\times$ I5.)

The second type, seen only in two cases, was much larger extending over many segments such as the whole cervical and upper thoracic regions. The cavities were lined by a thin shell of gliosed white matter. They were not associated with any fracture of the vertebra and the injury to the spine was indirect. 
Two examples of the third type of haematomyelia were encountered and in these haemorrhage into a pre-existing syringomyelia was proved. In these cases the cavities were most extensive involving almost the whole length of the spinal cord. Their wall was composed of a thick layer of very dense glial tissue which in some places contained numerous capillary vessels. The trauma was minimal in these cases.

Blackwood (1958) stated that it is doubtful whether mechanical trauma ever produced haematomyelia. These four cases show that it can occasionally happen especially if there is pre-existing disease. It could be argued that syringomyelia was already present in all four cases prior to injury. The fact that haemorrhage occurred in previously healthy active men engaged in heavy work does not support this idea in the first two examples, and the lining of the cavities was much thinner and less densely gliosed than in the latter two.

3. Arterial Changes. Although vessels occluded with fibrin thrombus were found within 24 hours of injury, organisation with recanalisation of the vessel was seen in cases surviving one year or more (fig. 9). The longest time interval elapsing

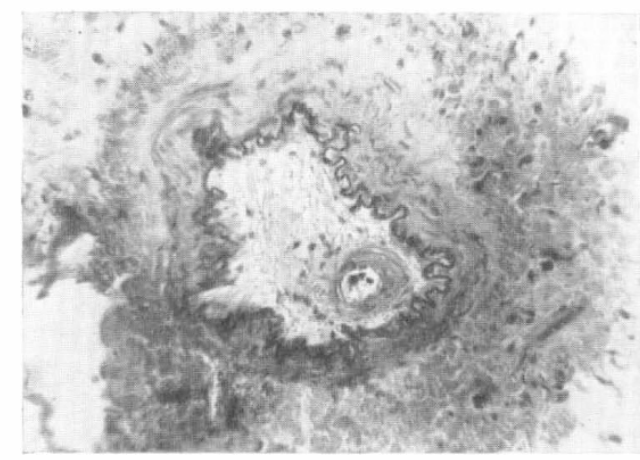

FIG. 9

(a) Anterior spinal artery at $\mathrm{S}_{3}$ showing old traumatic thrombosis with organisation and recanalisation. Male, aged 48 . Survived I year after fracture dislocation Di2-Li. (Elastic-Masson $\times$ I 20.)

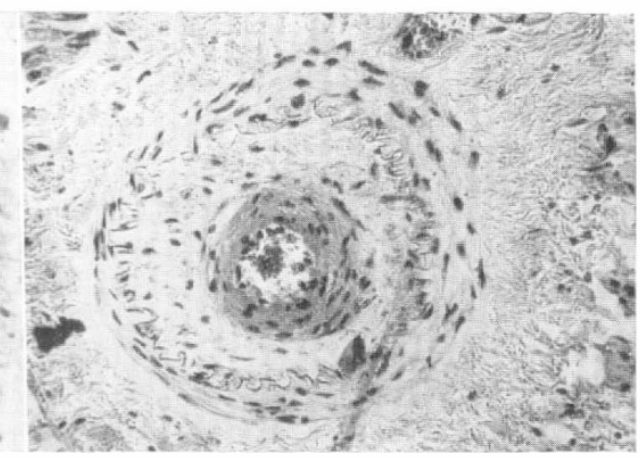

(b) Recanalised anterior spinal artery at D6 Io years after fracture dislocation D5-6. Male, aged 32. The surrounding pia arachnoid is thickened. (Elastic-Masson $\times$ I Io.)

since injury and the finding of occluded vessels was in a case surviving I I years after a lumbar spinal injury where small pial arteries on the dorso-lateral aspect of the cord were found with metastatic calcification and recanalisation (fig. I0).

The only other vascular change encountered was the severe intimal proliferation seen after intrathecal alcohol (fig. II) and in one case who developed paraplegia after spinal anaesthesia. In these cases there was also loss of elastica and replacement of fibrous tissue in pial vessels. Another marked feature of spinal vessels after intrathecal alcohol was a curious hyalinisation (fig. 12). This was also seen in vasa nervorum of the nerve roots of the cauda equina in long survival cases even if alcohol had not been given intrathecally (fig. I3). Similar but less marked changes have been seen in old age and in some of the vessels in venous angiomata of the spinal cord (Wyburn-Mason, I943). 


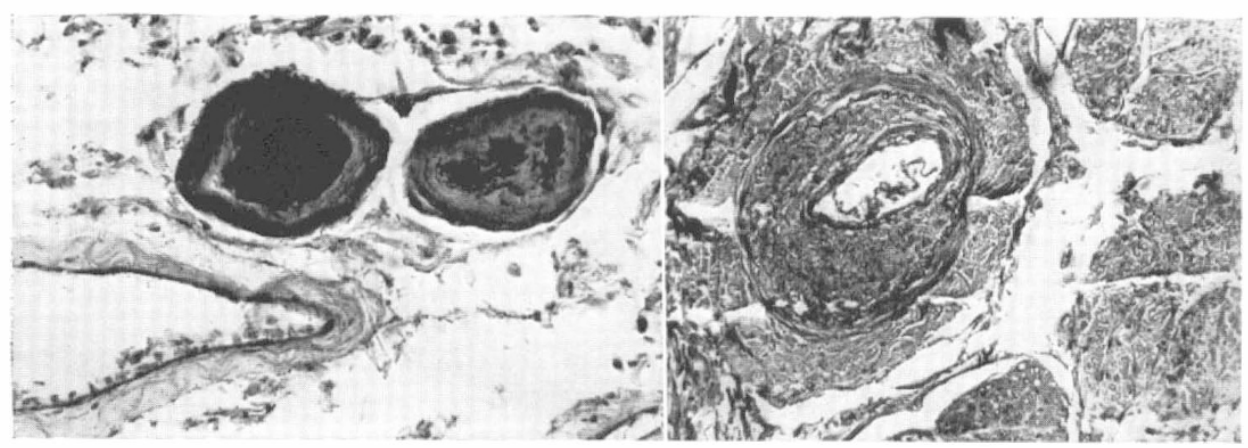

Fig. IO

FIG. II

Two small occluded arteries in the thickened pia arachnoid on dorsal aspect of cord at $\mathrm{L}_{3}$. Calcium deposition has occurred in the centre which shows minute recanalisation. Male, aged 4I. Survived IO $\frac{3}{4}$ years after fracture dislocation DI2-LI. (H. \& E. × I7O.)

Transverse section of pial artery on lateral aspect of cord at $\mathrm{L}_{4}$ showing severe intimal proliferation and fragmentation of internal elastic lamina. Male, aged 25. Survived $5 \frac{1}{2}$ years after fracture dislocation $\mathrm{D}_{4}-5$. Given intrathecal alcohol 2 years prior to death. (Elastic-Masson $\times$ IOO.)

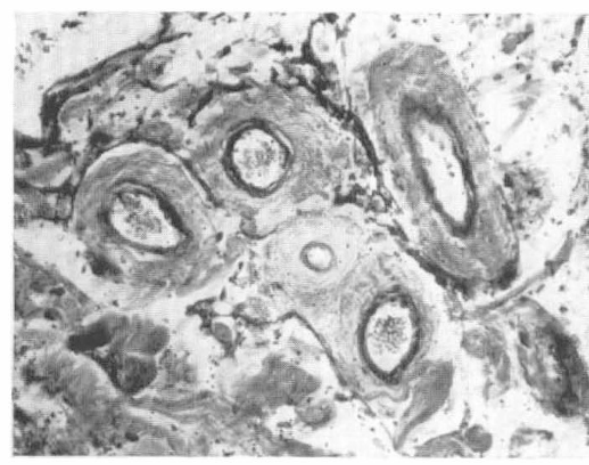

FIG. I2

Group of pial vessels on thelateral aspect of the cord at Di2 with thickened hyalinised walls. Male, aged 55. Spinal anaesthetic 9 years previously followed 4 years later by intrathecal alcohol. (Elastic-Masson × I00.)

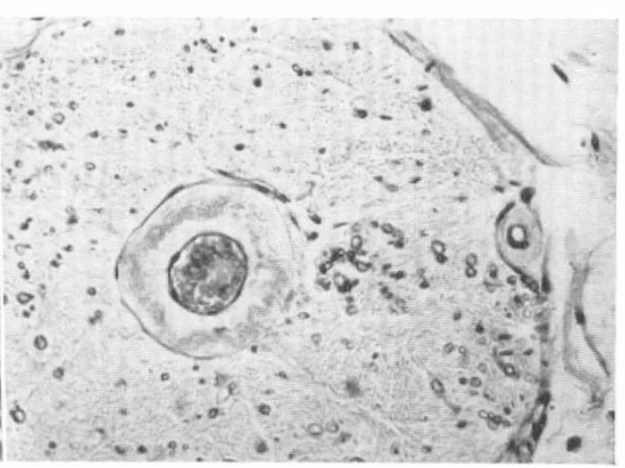

FIG. I3

Transverse section of nerve root at $\mathrm{L}_{3}$ showing vasa nervorum with thickened hyalinised walls and severe demyelination. Male, aged 48 . Survived $4 \frac{1}{3}$ years after fracture dislocation D I I-I2. (Myelin × I70.)

\section{SUMMARY}

An analysis of 95 cases of paraplegia examined at post-mortem has been made to ascertain the pathological effects of circulatory disturbances occurring within the first month and in later stages.

The effects have been subdivided into those found on general autopsy and the ones revealed by detailed examination of the spinal cord.

In the acute stage pulmonary embolus was found in only five cases and was never a cause of death after the first month. Severe pulmonary oedema was a 
frequent finding in cases dying after cervical injury being present in 20 out of 30 cases dying in the first II days. The possible mechanisms in its production are discussed. Heart failure due to coronary thrombosis occurred in five cases in the late stage of paraplegia but this did not appear to be related in any way to the injury being in an age group when this was a common mishap.

In the spinal cord haemorrhage, contusion, compression and thrombosis were frequent occurrences. Vertebral artery occlusion was not a common finding in cervical injuries but when it did occur affected predominantly the brainstem and cerebellum. Occlusion of pial arteries or of intramedullary vessels was seen in 20 cases and was most likely to be found after fracture dislocations causing compression.

In the late stages haematomyelia, recanalisation of thrombosed arteries and thickening with hyalinisation of the walls of blood vessels in the cord remnant or its coverings were found.

\section{RÉSUMÉ}

Une étude portant sur l'autopsie de 95 cas de paraplégie a été effectuée afin de verifier les effets pathologiques des atteintes circulatoires qui se produisent au décours du premier mois qui suivent la lésion.

Les effets ont été divisés entre ceux retrouvés d'une façon patente au moment de l'autopsie et ceux qui ont été révélés au cours de l'examen détaillé de la moëlle épinière.

Dans la phase aigue l'embolie pulmonaire a été trouvée dans 5 cas seulement et n'a jamais été cause de la mort après le premier mois.

L'oedeme pulmonaire sévère a été retrouvé comme cause fréquente de décès de malades atteints de lésion cervicale dans 20 cas sur 30 de ceux qui sont morts dans les premiers I I jours. La pathogénie possible a été discutée. La décompensation cardiaque à la suite d'infarctus du myocarde est survenue dans 5 cas dans une période ulterienze mais sans relation avec l'atteinte médulaire, ces malades appartenant à un groupe d'age où ces accidents sont fréquents.

Au niveau de la moëlle épinière l'hémorragie, la contusion, la compression et la thrombose sont des atteintes fréquentes. L'occlusion de l'artère vertebrale n'a pas été retrouvée d'une façon fréquente mais lorsqu'elle etait présente l'atteinte prédominante a été celle du bulbe et du cervelet. L'occlusion des artères de la pie-mère et des vaisseaux intra-médullaires a été retrouvé dans 20 cas et sont particulierement fréquentes après une fracture dislocation causant une compression de la moëlle.

Dans les stades ulterieurs de la paraplégie l'hematomyelie, le recanalisation des artères thrombosées ainsi que l'hyalinisation des parois des vaisseaux médullaires restants et des méninges a été trouvée.

\section{ZUSAMMENFASSUNG}

95 Obduktionsfälle von Paraplegie wurden untersucht mit besonderer Beücksichtigung der Folgen von Zirkulationsstörungen im ersten Monat und später.

Die Folgezustände wurden unterteilt in zwei Gruppen: diejenigen, die bei der allgemeinen Obduktion gefunden wurden und diejenigen, die sich bei der speziellen Untersuchung des Rückenmarks ergaben. Im akuten Stadium wurde Lungenembolie in nur 5 Fällen gefunden und-nach dem ersten Monat-war nie die Todesursache.

Schweres Lungenödem lag in vielen Fällen nach Zervikalverletzung vor bei 20 von 30 Todesfällen innerhalb der ersten I I Tage.

Die wahrscheinliche Pathogenese wird erörtert.

Versagen des Herzens als Folge einer Coronarthrombose fand sich in 5 späten Todesfällen. Dies hatte anscheinend keinerlei Zusammenhang mit der Verletzung, da es in der Altersgruppe gefunden wurde, in der Coronarthrombose häufig ist.

Im Rückenmark waren Blutung, Kontusion, Kompression und Thrombose häufige Befunde. Verschluss der A. vertebralis in Zervikalläsionen war selten. Wo er bestand, fanden sich die Folgezustände im Hirnstamm und Kleinhirn. 
Verschluss der Arterien der Pia und intramedullärer Gefässe lag in 20 Fällen vor, besonders nach Luxationsfrakturen mit Kompression.

In Spätfällen wurde Haematomyelie, Rekanalisation thrombotisch verschlossener Arterien und Verdickung und Hyalinablagerung der Gefässwände in der Rückenmarksnarbe oder ihrer Umgebung gefunden.

\section{REFERENCES}

Antonini, A. \& Biancolani, A. (1927). Arch Antrop.crim. 47, 747.

BAKer, A. B. (I957). Neurology, 7, 743.

Blackwood, W. (1958). In Greenfield, J. G., Blackwood, W., McMenemey, W. H., Meyer, A. \& Norman, R. M. Neuropathology, chap. 2, p. I I 5. London: Arnold.

Borison, H. L. \& Kovacs, B. A. (1959). F. Physiol. 145, 374.

Breithaupt, D. J., Jousse, A. T. \& Wynn-Jones, M. (i96i). Canad. med. Ass. F. 85, 73.

BRUNN, F. (1932). Wein. klin. Wschr. 45, I425.

Cameron, G. R. (1948). Brit. med. F. 1, 965

Cameron, G. R. \& De, S. N. (I949). F. Path. Bact. 6i, 375.

CAMERON, \& SHEIKH, (I95I).

Campbell, G. S. \& Visscher, M. B. (i949). Amer. F. Physiol. 157, i 30.

Camprell, G. S., Haddy, F. J., Adams, W. L. \& Visscher, M. B. (I949). Amer. F. Physiol. 58, 98.

Cornil, H., Hamant, A. \& Mosinger, M. (I930). Ann. Méd. 28, 453.

Dietrick, R. B. \& Russi, S. (I958). F. Amer.med. Ass. 166, 4 I.

Durbin, F. C. (I96I). Proc. R. Soc. Med. 54, 367.

Elliot, A. (1955). Acta med. scand. r50, 467.

FARBER, S. (I937). F. exp. Med. 66, 405.

Ford, F. R. \& Clark, D. (1956). Bull. Fohns Hopk. Hosp. 98, 37.

Gamble, J. E. \& Patton, H. D. (1953). Amer. F. Physiol. 172, 623.

Grinker, R. \& GuY, C. (I927). F. Amer. med. Ass. 88, i I4O.

HARrison, W. \& Liebow, A. A. (I952). Circulation, 6, 824.

Hess, L. (1934). Wien. med. Wschr. 84, 285.

Horst, H. G., Legler, H. \& Wegener, F. (I950). Z. ges. exp. Med. I16, I79.

Hughes, J. T. (I964). Int. F. Paraplegia, $2,2$.

JARISCH, A., Richter, H. \& Thoma, H. (I939). Klin. Wschr. r8, I440.

JELlinger, K. (I964). Acta neuropath. 3, 45I.

LoRD, K. H. \& BunTs, R. C. (I956). f. Urol. 75, 66.

Maire, F. W. \& Patton, H. D. (I956). Amer. F. Physiol. 184, 345.

Munro, D. (1943). F. Amer. Med. Ass. I22, I055.

Paine, R., Smith, J. R. \& Howard, F. A. (r952). J. Amer. med. Ass. 149, 643.

Pratt-Thomas, H. R. \& Berger, K. E. (1947). F. Amer. med. Ass. 133, 600.

Rech, R. H., McCarthy, L. E. \& Borison, H. L. (I962). Amer. F. Physiol. 203, i 5 I.

RICHARDS, P. (I963). Brit. med. F. 2, 83.

Sarnoff, S. J. \& Berglund, E. (I952). Amer. F. Physiol. 70, 588.

SARNOFF, S. J. \& SARNOFF, L. C. (I952). Circulation, 6, 5 I.

SChlesinger, B. (I945). F. nerv. ment. Dis. I02, 247.

Schneider, R. C., Thompson, J. M. \& Bebin, J. (1958). F. Neurol. Neurosurg. Psychiat. 2I, 2 I 6 .

Suechting, R. L. \& French, L. A. (1955). f. Neurosurg. 12, I87.

Tribe, C. R. (1963). Int. F. Paraplegia, I, I9.

Vincent, C. \& Bernard, E. (I926). Bull. Soc. méd. Hôp. Paris, 46, i I8I.

Visscher, M. B., Haddy, F. J.\& Stephens, G. (I956). Pharmacol.Rev. 8, 389.

WEISMAN, S. J. (I939). Surgery, 6, 722.

Wyburn-Mason, R. (I943). The Vascular Abnormalities and Tumours of the Spinal Cord and its Membranes, chap. 3, p. Io. London: Kimpton.

Yates, P. O. (1959). Arch. Dis. Childh. 34, 436. 